\title{
本みりんの貯蔵着色と機能性
}

近年, 消費者の健康志向を反映して清酒, ビール, ワインなどの酒類や味噌, 奨油, 食酢などの伝統的醸 造食品の三次機能に関する研究報告が, 数多く成されている。今回は, 本みりん中から分離・精製した貯蔵 着色物質メラノイジンの諸性質及び抗酸化性と血圧上昇抑制に関わるアンジオテンシン I 変換酵素阻害活性 という機能性について筆者らの研究成果を解説していただいた。

\section{高橋康 次郎・竹村朋実}

\section{1. はじめに}

近年, 食品の安全安心とともに, 食品への健康志向 の高まりから, 生体調節に関する食品の三次機能が注 目されており,これまでに滰油, 味増, 食酢, 納豆な どの伝統的な醸造食品や清酒，ビール，ワイン等の酒 類で多くの研究が行われてきている。これらの成果は, 2007 年に北本勝ひこ氏を会長とする日本生物工学会 スローフード微生物工学研究部会から「醉造物の機能 性」として刊行された ${ }^{1)}$ 。

本みりんの機能性に関するこれまでの研究は, 一次 機能といわれる糖質, タンパク質や脂質など成分に関 する研究や, 二次機能である調味効果に関する研究 ${ }^{2)}$ が主で，三次機能に関する研究は余り行われなかった。 しかし, 最近になって, 本みりんの抗酸化性や血圧上 昇抑制効果についての研究がいくつか行われている。

抗酸化性に関しては, 石崎ら ${ }^{3)}$ は, 通常の市販本み りんにはみりん風調味料の約 3 倍の抗酸化性があり, その効果を示す主要成分がアミノ・カルボニル反応の 初期段階で生成するアマドリ転移化合物（フラクトー スーヒスチジン (Frc-His), フラクトースーメチオニ ン (Frc-Met)，フラクトースーグルタミン酸（FrcGlu), フラクトースーフェニルアラニン (Frc-Phe) であることを明らかにし，実際にイワシのみりん干し においてみりん風調味料等よりも強い脂質酸化抑制効
果があることを報告している ${ }^{3-5)}$ 。また，松田ら ${ }^{6)}$ は， 本みりんを 2 倍に加熱濃縮したものを摂取した場合, 摂取後の尿中のクレアチニン当りの 8 -ヒドロキシデ オキシグアノシン $(8-\mathrm{OHdG})$ 量が減少し, 生体内 で酸化ストレスが抑制されることを明らかにした。

一方，本みりんの血圧上昇抑制効果に関しては，松 田ら ${ }^{7)}$ は, 自然発症高血圧ラット (SHR) に本みりん の 2 倍濃縮物を経口投与したところ, 軽度の血圧降下 作用を示したことを報告し, 福井ら ${ }^{8)}$ は, アンジオテ ンシン I 変換酵素（ACE）阻害活性を有する 4 種類 のペプチドを分離したことを報告している。

筆者らは, 本みりんの成分的特徵である高糖濃度, 高窒素分に着目しアミノ・カルボニル反応の後期段階 で生成する着色物質メラノイジンの機能性, 特に抗酸 化性 ${ }^{9)}$ 及び血圧上昇抑制効果 ${ }^{10)}$ について検討した。

メラノイジンの機能性についてはこれまで抗酸化性 ${ }^{11)}$ のほか, 活性酸素消去作用 ${ }^{12)}$, 抗菌作用 ${ }^{13)}$, 抗変 異原性 ${ }^{14)}$, 発ガン抑制作用 ${ }^{15)}$, 植物繊維様作用 ${ }^{16)}$, 高 血圧抑制効果 ${ }^{17,18)}$ など多数報告されている。しかし, 対象メラノイジンはモデル系による糖とアミノ酸から 加熱合成されものがほとんどであり, 実際の食品や釀 造物のメラノイジンに関しての報告は少ないのが現状 である。

Effect of Color Substances of Stored Hon-mirin on the Physiological Function of it

Kojiro Takahashi and Tomomi Takemura (Department of Fermentation Science, Faculty of Applied Bioscience, Tokyo University of Agriculture) 


\section{2. 市販本みりんの着色度と機能性との関係 ${ }^{10}$}

市販の本みりんには，90\%以上の消費量を占める糖 類使用本みりんの他，糖類を使用しない純米本みりん，
1 年から 3 年または 10 年程度熟成させた長期貯蔵本 みりんの 3 タイプがあり, これら 20 種類の本みりん の各種成分と抗酸化性及びアンジオテンシン I 変換酵 素（ACE）阻害活性との関係を検討し，第 1 表に成

第 1 表 市販本みりんの各種成分

\begin{tabular}{|c|c|c|c|c|c|c|c|c|c|c|c|c|c|c|}
\hline \multicolumn{2}{|c|}{$\begin{array}{l}\text { 本みりん } \\
\text { のタイプ }\end{array}$} & ボーメ & $\mathrm{pH}$ & $\begin{array}{l}\text { 酸度 } \\
(\mathrm{ml})\end{array}$ & $\begin{array}{c}\text { アミノ } \\
\text { 酸度(ml) }\end{array}$ & $\begin{array}{l}\text { アルコー } \\
\text { ル分 }(\%)\end{array}$ & $\begin{array}{l}\text { エキス } \\
\text { 分 }(\%)\end{array}$ & $\begin{array}{l}\text { グルコ } \\
\text { ース(\%) }\end{array}$ & $\begin{array}{c}\text { 総フェノー } \\
\text { ル量 } \\
(\mathrm{mg} / 100 \mathrm{ml})\end{array}$ & $\begin{array}{c}\text { FRS } \\
\left(O D^{660 \mathrm{~nm}}\right)\end{array}$ & $\begin{array}{l}3-\mathrm{DG} \\
\left(\mathrm{OD} \mathrm{D}^{530 \mathrm{~nm}}\right)\end{array}$ & $\begin{array}{l}\text { 着色度 } \\
\left(\mathrm{OD}^{430 \mathrm{~nm}}\right)\end{array}$ & $\begin{array}{l}\text { DPPH ラ } \\
\text { ジカル消 } \\
\text { 去率 }(\%)\end{array}$ & $\begin{array}{l}\mathrm{ACE} \text { 阻 } \\
\text { 害率(\%) }\end{array}$ \\
\hline \multirow{6}{*}{$\begin{array}{l}\text { 糖 } \\
\text { 類 } \\
\text { 使 } \\
\text { 用 }\end{array}$} & 1 & 19.0 & 5.7 & 0.2 & 1.9 & 12.5 & 43.1 & 28.6 & 45.9 & 0.99 & 0.8 & 0.085 & 1.4 & 33.5 \\
\hline & 2 & 19.5 & 5.9 & 0.1 & 1.1 & 12.5 & 44.3 & 28.9 & 22.9 & 0.68 & 0.7 & 0.076 & 2.4 & 43.5 \\
\hline & 3 & 20.5 & 5.3 & 0.2 & 1.1 & 13.8 & 46.8 & 27.8 & 22.7 & 0.98 & 2.3 & 0.116 & 2.8 & 29.6 \\
\hline & 4 & 19.8 & 5.7 & 0.1 & 1.2 & 13.5 & 45.6 & 29.4 & 25.0 & 0.69 & 0.3 & 0.085 & 5.6 & 20.7 \\
\hline & 5 & 24.0 & 5.7 & 0.6 & 2.0 & 11.5 & 54.9 & 25.5 & 49.5 & 1.56 & 3.4 & 0.189 & 5.2 & 67.8 \\
\hline & 6 & 20.4 & 5.7 & 0.2 & 1.2 & 14.0 & 46.5 & 27.7 & 23.2 & 0.73 & 0.9 & 0.093 & 1.9 & 26.0 \\
\hline \multicolumn{2}{|c|}{ 平均值 } & 20.53 & 5.67 & 0.23 & 1.42 & 12.97 & 46.87 & 27.98 & 31.53 & 0.940 & 1.40 & 0.1073 & 3.22 & 36.85 \\
\hline \multirow{7}{*}{$\begin{array}{l}\text { 純 } \\
\text { 米 }\end{array}$} & 7 & 19.3 & 5.9 & 0.2 & 1.7 & 14.3 & 44.1 & 30.2 & 68.2 & 1.12 & 1.1 & 0.082 & 1.3 & 43.5 \\
\hline & 8 & 20.1 & 5.7 & 0.3 & 1.3 & 13.5 & 46.1 & 32.6 & 80.7 & 1.46 & 1.7 & 0.129 & 2.5 & 49.6 \\
\hline & 9 & 18.6 & 5.4 & 0.4 & 2.6 & 14.8 & 42.4 & 31.4 & 99.1 & 1.91 & 3.0 & 0.183 & 4.7 & 56.1 \\
\hline & 10 & 20.1 & 5.7 & 0.4 & 3.5 & 14.0 & 45.9 & 28.9 & 156.3 & 3.54 & 6.9 & 0.306 & 7.8 & 64.3 \\
\hline & 11 & 19.7 & 4.6 & 1.4 & 3.1 & 14.3 & 44.9 & 30.7 & 114.2 & 2.18 & 2.4 & 0.468 & 8.0 & 81.7 \\
\hline & 12 & 19.7 & 5.7 & 0.3 & 1.7 & 13.8 & 44.9 & 37.6 & 86.0 & 1.95 & 3.8 & 0.242 & 4.8 & 39.7 \\
\hline & 13 & 19.2 & 5.1 & 1.5 & 4.3 & 13.8 & 44.2 & 33.9 & 163.2 & 3.17 & 8.7 & 0.380 & 7.6 & 59.8 \\
\hline \multicolumn{2}{|c|}{ 平均値 } & 19.53 & 5.44 & 0.64 & 2.60 & 14.07 & 44.64 & 32.19 & 109.67 & 2.190 & 3.94 & 0.2557 & 5.24 & 56.39 \\
\hline \multirow{7}{*}{$\begin{array}{l}\text { 長 } \\
\text { 期 } \\
\text { 貯 } \\
\text { 蔵 }\end{array}$} & 14 & 20.4 & 5.1 & 1.1 & 3.4 & 14.3 & 46.4 & 32.7 & 83.3 & 4.10 & 11.6 & 1.148 & 16.9 & 64.5 \\
\hline & 15 & 20.5 & 4.2 & 2.2 & 2.0 & 14.3 & 46.9 & 31.8 & 65.0 & 2.66 & 9.4 & 1.081 & 7.1 & 64.7 \\
\hline & 16 & 20.4 & 5.1 & 0.9 & 2.8 & 14.5 & 46.3 & 32.6 & 133.6 & 4.41 & 25.5 & 9.841 & 29.1 & 86.0 \\
\hline & 17 & 18.8 & 4.4 & 3.5 & 4.8 & 13.8 & 42.7 & 28.3 & 120.1 & 6.87 & 39.4 & 0.889 & 6.5 & 81.4 \\
\hline & 18 & 20.6 & 4.2 & 4.3 & 4.3 & 13.8 & 46.8 & 31.8 & 234.7 & 8.92 & 43.1 & 10.767 & 42.3 & 97.7 \\
\hline & 19 & 18.6 & 5.1 & 1.0 & 3.9 & 15.0 & 42.1 & 31.2 & 81.6 & 3.57 & 10.2 & 1.228 & 6.4 & 57.8 \\
\hline & 20 & 18.2 & 4.1 & 1.7 & 2.3 & 15.0 & 42.4 & 28.5 & 90.3 & 3.68 & 15.3 & 6.565 & 21.8 & 87.3 \\
\hline \multicolumn{2}{|c|}{ 平均値 } & 19.64 & 4.60 & 2.10 & 3.36 & 14.39 & 44.80 & 30.99 & 115.51 & 4.901 & 22.07 & 4.5030 & 18.59 & 77.06 \\
\hline
\end{tabular}

総フェノール量はチロシンとして表示。FRS：フェリシアナイド還元值，3-DG：3- デオキシグルコソン,

DPPH : 1,1- ジフェニルー2-ピクリルヒドラジル, ACE : アンジオテンシン I 変換酵素 .

第 2 表 各成分間の相関関係

\begin{tabular}{|c|c|c|c|c|c|c|c|c|c|c|c|c|c|}
\hline 成分項目 & 1 & 2 & 3 & 4 & 5 & 6 & 7 & 8 & 9 & 10 & 11 & 12 & 13 \\
\hline 1 ボーメ & 1.000 & & & & & & & & & & & & \\
\hline $2 \mathrm{pH}$ & 0.190 & 1.000 & & & & & & & & & & & \\
\hline 3 酸度 $(\mathrm{ml})$ & -0.057 & $-0.852^{* *}$ & 1.000 & & & & & & & & & & \\
\hline 4 アミノ酸度 $(\mathrm{ml})$ & -0.205 & $-0.562^{* *}$ & $0.717^{* *}$ & 1.000 & & & & & & & & & \\
\hline 5 アルコール分(\%) & $-0.598^{* *}$ & $-0.463^{*}$ & 0.206 & 0.321 & 1.000 & & & & & & & & \\
\hline 6 エキス分（\%） & $0.995^{* *}$ & 0.177 & -0.066 & -0.232 & $-0.591^{* *}$ & 1.000 & & & & & & & \\
\hline 7 グルコース（\%） & -0.268 & -0.084 & 0.090 & 0.198 & 0.390 & -0.281 & 1.000 & & & & & & \\
\hline 8 総フェノール量 (mg/100ml) & -0.101 & $-0.502^{* *}$ & $0.685^{* *}$ & $0.801^{* *}$ & 0.308 & -0.114 & 0.395 & 1.000 & & & & & \\
\hline 9 FRS $\left(\mathrm{OD}^{660 \mathrm{~nm}}\right)$ & -0.076 & $-0.706^{* *}$ & $0.897^{* *}$ & $0.826^{* *}$ & 0.293 & -0.099 & 0.188 & $0.823^{* *}$ & 1.000 & & & & \\
\hline $103-\mathrm{DG}\left(\mathrm{OD}^{530 \mathrm{~nm}}\right)$ & -0.062 & $-0.689^{* *}$ & $0.887^{* *}$ & $0.711^{* *}$ & 0.220 & -0.086 & 0.094 & $0.703^{* *}$ & $0.958^{* *}$ & 1.000 & & & \\
\hline 11 着色度 $\left(O D^{430 n m}\right)$ & 0.015 & $-0.558^{* *}$ & $0.570^{* *}$ & 0.340 & 0.287 & 0.011 & 0.151 & $0.603^{* *}$ & $0.694^{* *}$ & $0.735^{* *}$ & 1.000 & & \\
\hline 12 DPPH ラジカル消去率 (\%) & 0.075 & $-0.606^{* *}$ & $0.655^{* *}$ & $0.472^{*}$ & 0.282 & 0.070 & 0.212 & $0.703^{* *}$ & $0.787^{* * *}$ & $0.764^{* *}$ & $0.951^{* *}$ & 1.000 & \\
\hline 13 ACE 阻害率（\%) & 0.041 & $-0.750^{* *}$ & $0.752^{* *}$ & $0.703^{* *}$ & 0.278 & 0.038 & 0.095 & $0.751^{* *}$ & $0.798^{* *}$ & $0.742^{* *}$ & $0.683^{* *}$ & $0.734^{* *}$ & 1.000 \\
\hline
\end{tabular}
$\mathrm{n}=20, \quad \mathrm{r}(18,0.05)=0.444\left(^{*}\right), \quad r(18, \quad 0.01)=0.561\left(^{* *}\right)$ 
分分析值を，第 2 表に各成分間の相関関係を示した。 ここで，抗酸化性はKitagaki ら ${ }^{19)}$ の方法による DPPH ラジカル消去率（％）を使用し，ACE 阻害率 は（株）同仁化学研究所製 ACEkit-WSTにより測定 した。なお，抗酸化性は，ラジカル消去率が $50 \%$ と なる時のサンプル濃度 $\left(\mathrm{IC}_{50}\right)$ を求め, ビタミン $\mathrm{E} の$ 同族体である Trolox の $\mathrm{IC}_{50}$ と比較し, サンプル $100 \mathrm{ml}$ 当たりのラジカル消去活性を Trolox 当量 $(\mu$ $\mathrm{mol} / 100 \mathrm{ml}$ ）として示す場合もある。

第 1 表において 3 つのタイプの平均値を比較すると， $\mathrm{pH}$ は長期貯蔵本みりんで大きく下がり, 酸度の増加 によることが推定された。清酒で貯蔵着色と相関が高 いといわれている総フェノール量 ${ }^{20)}$, フェリシアナ イド還元值 $(\mathrm{FRS})^{21}$ 及び 3 -デオキシグルコソン $(3$ - DG ${ }^{22)}$ は着色度とともに長期貯蔵本みりんで極端 に高く, 次いで, 純米本みりんの順であり, 貯蔵期間 の短い糖類添加本みりんではいずれも小さな值であっ た。抗酸化性及び ACE 阻害活性も着色度の場合と同 様, 長期貯蔵本みりんで大きく増加した。

第 2 表の相関係数から, 着色度と抗酸化性との間に $r=0.951$, 着色度と $\mathrm{ACE}$ 阻害活性との間に $\mathrm{r}=0.683$, 抗酸化性と ACE 阻害活性との間に $\mathrm{r}=0.734$ (いず れも $\mathrm{n}=20$ ）と，1\%以下の危険率で高度に有意な相 関関係が認められた。両機能性とその他の成分との関 係をみると, $\mathrm{pH}$, 酸度, アミノ酸度等との相関関係 が高いこと, さらに, 総フェノール量やFRS, アミ ノ・カルボニル反応の中間体である $3-D G$ 等と相関 が高いことから, 機能性の発現には本みりんの貯蔵に よる着色反応が密接な関係にあると推定された。そこ で，本みりんの着色物質を分離・精製し機能性との関 係を検討した。

\section{3. 本みりんの着色物質と抗酸化性との関係 ${ }^{9}$}

\section{1）本みりんの着色物質の分離・精製}

第 3 表に示した貯蔵期間の異なる本みりん 3 種類 $(\mathrm{A}$ ：短期貯蔵, B : 3 年貯蔵, $\mathrm{C}: 10$ 年貯蔵) を試料 として着色物質の分離・精製を行った。

それぞれ $100 \mathrm{ml}$ の本みりんを蒸留水で 3 倍に希釈 し，高分子の吸着に優れた合成吸着剤 DiaionHP20 $140 \mathrm{ml}$ を充填したカラム $(2.8 \mathrm{cmx} 30 \mathrm{~cm})$ に通した後, カラムを流液に糖分, アミノ酸, 有機酸の反応がなく なるまで蒸留水で洗浄した。吸着された着色物質を $60 \%$ メノール (pH5.5, 試料 Cの場合は $99 \%$ メ ノール） $420 \mathrm{ml}$ で溶出し, 各フラクションについて着 色度と Trolox 当量を測定した。試料 B のクロマトグ ラムの結果を第 1 図に示したが, 各画分の着色度と Trolox 当量の值がよく一致したことから, 着色物質 が抗酸化性を示すことが示唆された。試料 A 及び C のクロマトグラムでも同様の結果であった。

なお，抗酸化性を示す着色区分をシリカゲル薄層に てn-BuOH : AcOH : $\mathrm{H}_{2} \mathrm{O}$ (4:1:2) の溶媒で展開し, $10 \%$ エタノルル性硫酸で発色を行ったところ, スポッ トは 1 個でありほぼ精製されていることを確認した。 次に, 着色物質の分子量を推定するためにゲルろ過ク ロマトグラフイーを行った。

\section{2）本みりん着色物質の分子量の推定}

Bio-Gel P100 ゲルを充填したカラム $(1.0 \mathrm{~cm} \times$ $50 \mathrm{~cm}$ ）に濃縮した着色区分をのせ, 純水で展開（流 速： $0.1 \mathrm{ml} / \mathrm{min}$ ）し， $1.5 \mathrm{ml}$ ずつ分取した。なお，分 子量マーカーとして Alubmin (Bovine selum): 分子 量 (MW) 66,000, Carbonic anhydrase: MW:29,000, Myoglobine equine：MW17,800を使用した。本みり ん B 及び C のクロマトグラムを第 2 図に示した。

精製した着色物質は抗酸化性のピークとよく一致し ていることがこの図からも分かる。以上から, 貯蔵し た本みりんの抗酸化性はメラノイジンそのものに起因 すると考えられた。

着色度当りの抗酸化性（Trolox eq. $/ \mathrm{OD}^{430 \mathrm{~nm}} / 100 ）$

第 3 表 着色物質の分離に用いた本みりんの性状

\begin{tabular}{|c|c|c|c|c|c|c|c|c|c|c|}
\hline 本みりん & $\mathrm{pH}$ & $\begin{array}{c}\text { アミノ酸度 } \\
(\mathrm{ml})\end{array}$ & $\begin{array}{l}\text { Alc. } \\
(\%)\end{array}$ & $\begin{array}{c}\text { エキス分 } \\
(\%)\end{array}$ & $\begin{array}{c}\text { 総フェノール量 } \\
(\mathrm{mg} / 100 \mathrm{ml})\end{array}$ & $\begin{array}{c}\text { FRS } \\
\left(\mathrm{OD}^{660 \mathrm{~nm}}\right)\end{array}$ & $\begin{array}{c}3-\mathrm{DG} \\
\left(\mathrm{OD}^{530 \mathrm{~nm}}\right)\end{array}$ & $\begin{array}{c}\text { 着色度 } \\
\left(\mathrm{OD}^{430 \mathrm{~nm}}, \mathrm{~A}\right)\end{array}$ & $\begin{array}{c}\text { 抗酸化性 } \\
\text { (B) }\end{array}$ & $\begin{array}{l}\text { OD 当り抗酸化 } \\
\text { 性 }(B / A / 100)\end{array}$ \\
\hline A 短期貯蔵 & 5.4 & 1.2 & 13.8 & 45.7 & 20.1 & 3.65 & 10.0 & 0.122 & 431.1 & 35.3 \\
\hline B 3 年貯蔵 & 5.5 & 1.2 & 14.5 & 50.7 & 18.3 & 2.99 & 15.7 & 0.676 & 1063.6 & 15.7 \\
\hline C 10 年貯蔵 & 4.2 & 0.6 & 14.0 & 48.1 & 26.6 & 3.58 & 17.4 & 10.641 & 2977.7 & 2.8 \\
\hline
\end{tabular}

総フェノール量は没食子酸として, また，抗酸化性は，Trolox 当量（ $\mu \mathrm{mol} / 100 \mathrm{ml} ）$ とした值である。

FRS : フェリシアナイド還元值, $3-\mathrm{DG}: 3$ - デオキシグルコソン。 


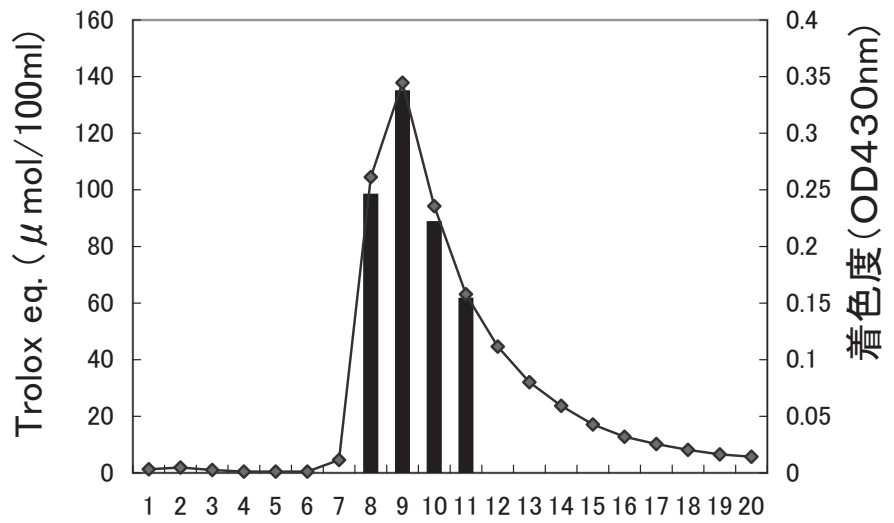

Fraction no.

Trolox eq. $(\mu \mathrm{mol} / 100 \mathrm{ml}) \rightarrow$ OD430nm

第 1 図 本みりん B の着色物質と抗酸化性との関係

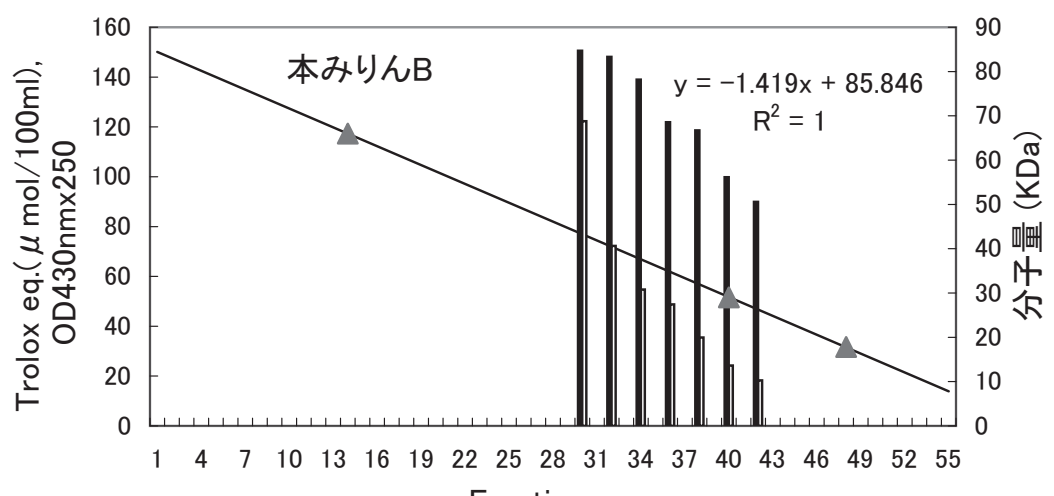

Fraction no.

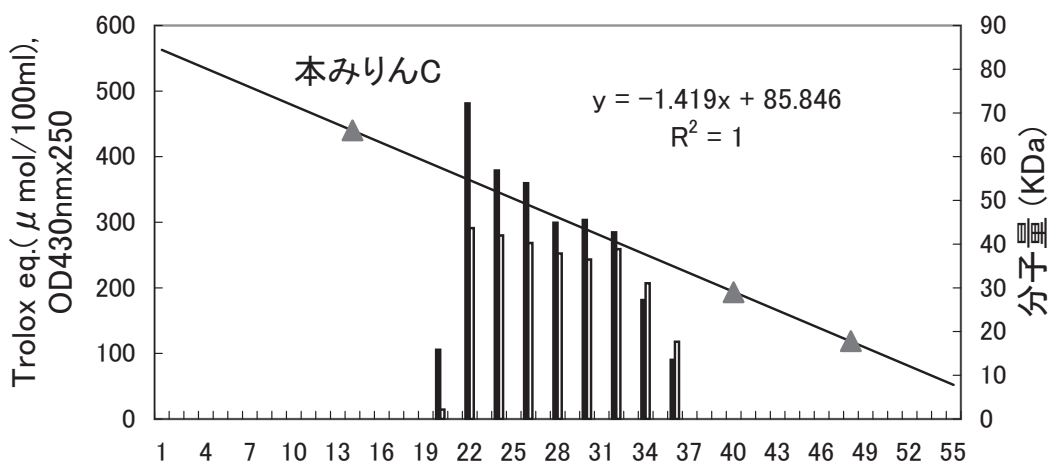

Fraction no.

Trolox eq. $\square$ OD430x250 - - MW-marker(KDa)

第 2 図 本みりん B 及び C の Bio-Gel P100 ゲルろ過クロマトグラフィー 
は, 本みりんそのものでは第 3 表に示したように, 貯 蔵の短い本みりんでは大きく, 貯蔵により熟成の進ん だ本みりんでは小さな值となったが, これは, 貯蔵期 間の短い本みりんは着色物質以外の成分の抗酸化性の 寄与が大きく, 貯蔵が進むほど着色物質の寄与が高く なってくることを示している。ちなみに, 結果は示し ていないが，短期貯蔵の本みりんでは着色区分と重な らない抗酸化性を示す区分が沢山見られたことからも 理解できる。な拉, 第 2 図のカラムクロマトグラフィ ーにより精製された着色物質の各区分について, 着色 度当たりの抗酸化性の值を求めると, 本みりん B で は平均 3.9 (最大 最小: $5.7 \sim 2.4$ ), 本みりん C では平均 3.2 (同: $4.1 \sim 1.9$ ) となり, ある程度貯 蔵した本みりんでは平均 3.55 (同 $5.7 \sim 1.9$ ) 程度の 小さな值に収束する傾向が見られた。

なお, ゲルクロマトグラフィーから推定される着色 物質の分子量は, 3 年貯蔵の本みりんBで 26 $43 \mathrm{KDa}, 10$ 年貯蔵本みりんCでは $34 \sim 57 \mathrm{KDa}$ と推
定され，貯蔵とともに着色物質が高分子化し，それに 伴い抗酸化性も増加することが認められた。ただ, 着 色度当りの抗酸化性は 3 年貯蔵と 10 年貯蔵でそれほ ど大きく変わらないことは興味深い結果といえる。

\section{3）本みりんの貯蔵による着色物質メラノイジン生成 の検証}

糖類とアミノ酸が存在するとアミノ・カルボニル反 応により最終的に着色物質メラノイジンが生成し, そ の中間体としていろいろの成分が報告されている ${ }^{23,24)}$

そこで, 本みりんの貯蔵中にアミノ・カルボニル反 応が実際に進行しメラノイジンが生成していることを 間接的に検証した。なお, 筆者の一人高橋ら ${ }^{25}$ は貯 蔵本みりんの着色物質を水飽和フェノールで抽出後, シリカゲルカラムクロマト次いで薄層クロマトにより 検討し, 主要成分はメラノイジンであることを報告し ている。

(1)着色物質の吸収スペクトル３種類の本みりんの DiaionHP20 クロマトで精製された着色区分の吸収

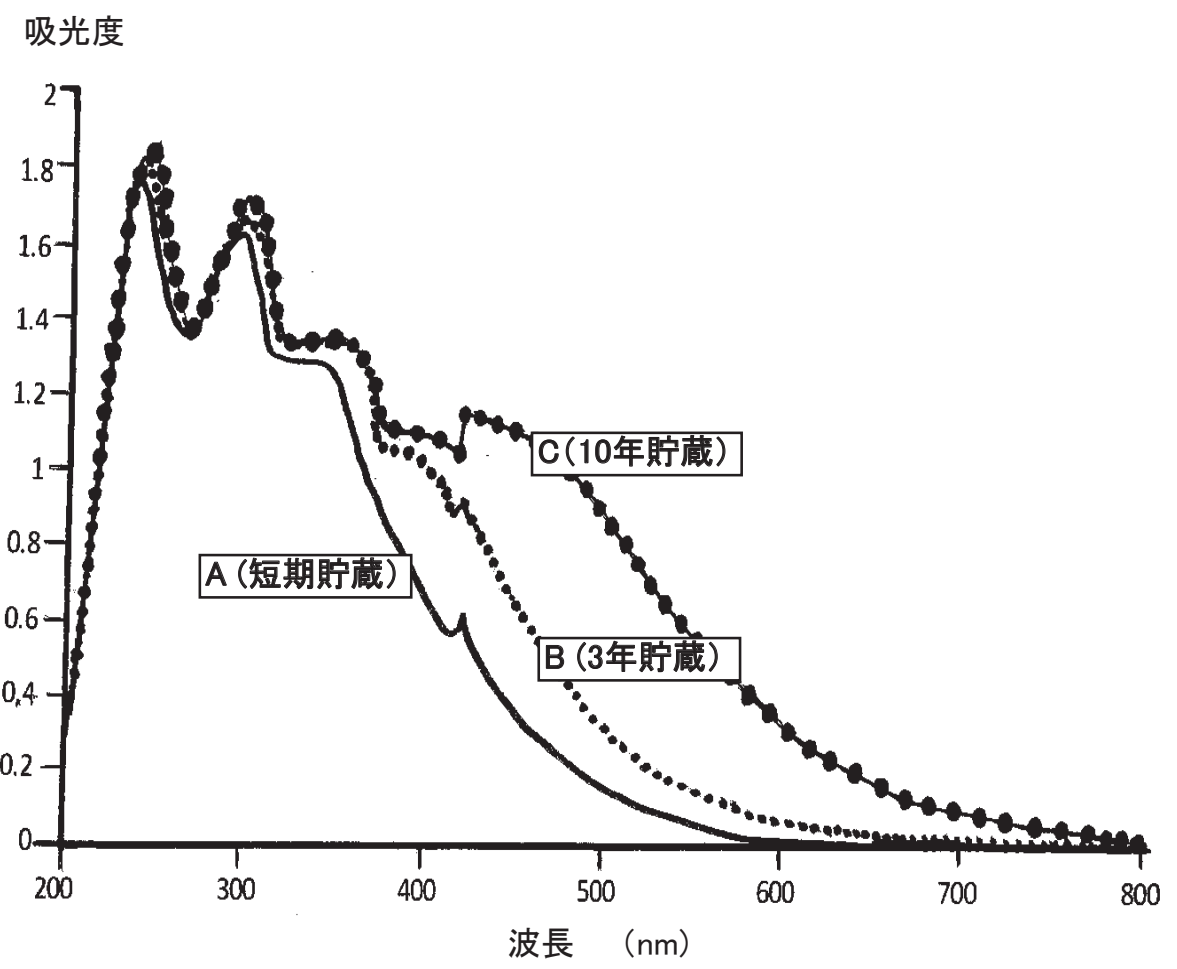

第 3 図 精製着色物質の吸収曲線 
スペクトルを第 3 図に示した。通常本みりんの吸収 スペクトルの可視部には吸収極大や曲線の肩などは 見られないが，精製した着色物質には $420 \mathrm{~nm} に$ に さな吸収極大が見られた。また，長波長側には吸収 極大はなく,メラノイジンに特徴的ななだらかな曲 線を示した ${ }^{26,27)}$ 。

(2)着色物質のアミノ酸組成本みりんBと C の着 色区分を $2 \mathrm{~N}$ 塩酸で $105^{\circ} \mathrm{C}, 24$ 時間加熱分解後アミ ノ酸を定量し組成比を第 4 表に示した。検出された アミノ酸の種類は, 3 年貯蔵本みりんでは 15 種類 と多く, 10 年貯蔵本みりんでは 7 種類に減少して いた。中では, Phe, Gluが割合として両本みりん に多く検出された。石崎ら ${ }^{3)}$ が短期貯蔵本みりんか ら分離したアマドリ転移化合物 Frc-His, Frc-Met,

第 4 表 精製着色物質のアミノ酸組成

\begin{tabular}{l|rr}
\hline \multirow{2}{*}{ アミノ酸 } & \multicolumn{2}{|c}{ アミノ酸組成比 $(\%)$} \\
\cline { 2 - 3 } & \multicolumn{2}{|c|}{ 本みりんの貯蔵年数 } \\
Asp & 2.0 & 10 年 \\
Thr & 2.0 & 0 \\
Ser & 3.2 & 0 \\
Glu & 7.4 & 24.0 \\
Gly & 2.1 & 15.0 \\
Ala & 4.8 & 0 \\
Cys & 12.9 & 0 \\
Val & 6.9 & 5.9 \\
Met & 0 & 0 \\
Ile & 5.5 & 0 \\
Leu & 8.2 & 5.9 \\
Tyr & 2.3 & 9.6 \\
Phe & 29.8 & 28.1 \\
Lys & 3.0 & 0 \\
NH3 & 0 & 0 \\
His & 3.8 & 11.5 \\
Arg & 6.1 & 0 \\
Pro & 0 & 0 \\
\hline 合計 & 100 & 100 \\
\hline
\end{tabular}

Frc-Glu 及び Frc-Phe のうち Met を除いた 3 種類の アミノ酸が着色物質に検出されたことは納得できる。 (3)アミノ・カルボニル反応中間体の検出 メラノイ ジンの生成過程で生じるとされる中間体 3-DGの值 を第 3 表に示したが, 本みりんの短期貯蔵：10.0, 3 年貯蔵: 15.7, 10 年貯蔵: 17.4（いずれも $\mathrm{OD}^{530 \mathrm{~nm}}$ として）と貯蔵期間とともに増加すること が確認された。また，3-DG から生成するとされる 5-Hydroxymethyl-2-furfural (HMF) についても, 本みりんの短期貯蔵 : 不検出, 3 年貯蔵 : $0.82,10$ 年貯蔵 : 2.14 (いずれも内部標準とのピーク比) と 貯蔵とともに増加することを認めた ${ }^{28)}$ 。また， メ ラノイジンから加熱により生成するとされる ${ }^{29)}$ 5-Methyl-2-furfural（MF）も10 年貯蔵本みりんに 検出された（短期貯蔵：不検出, 3 年貯蔵: 痕跡,

10 年貯蔵：ピーク比 0.11$)^{28)}$ 。

以上の結果から, 本みりんの貯蔵熟成中にアミノ・ カルボニル反応が進行し着色物質メラノイジンが生成 していることが間接的に立証されたといえる。

\section{4. 本みりんの着色物質と ACE 阻害活性との関係 ${ }^{10}$}

第 1 表から, 着色度と ACE 阻害活性との相関関係 が $\mathrm{r}=0.683(\mathrm{p}<0.01)$ と有意に高いことから, 本み りんの貯蔵による着色増加により ACE 阻害活性が増 加することが考えられた。そこで，まず，貯蔵年数の 異なる同一メーカーの本みりんの着色度と ACE 阻害 活性との関係を第 5 表に示した。

これから，ACE 阻害活性も前述した抗酸化性と同 じく貯蔵年数とともに増加すること, また, 着色度及 び着色増加に関係する各種成分と同じ挙動を示すこと が明らかとなった。そこで, 抗酸化性の場合と同様の 方法で着色物質を精製し, 着色物質そのものが $\mathrm{ACE}$ 阻害活性を示すかを検討した。

第 5 表 貯蔵年数の異なる本みりんの各種成分

\begin{tabular}{|c|c|c|c|c|c|c|c|c|}
\hline $\begin{array}{l}\text { 本みりん } \\
\text { 貯蔵(年) }\end{array}$ & $\begin{array}{c}\text { 総フェノール量 } \\
(\mathrm{mg} / 100 \mathrm{ml})\end{array}$ & $\begin{array}{c}\text { FRS } \\
\text { (OD660nm) }\end{array}$ & $\begin{array}{c}\text { 3-DG } \\
\text { (OD530nm) }\end{array}$ & $\begin{array}{l}\text { DPPH ラジカ } \\
\text { ル消去率 }(\%)\end{array}$ & $\begin{array}{c}\text { 着色度 } \\
(\mathrm{OD} 430 \mathrm{~nm}, \mathrm{~A})\end{array}$ & $\begin{array}{l}\text { ACE 阻害 } \\
\text { 率 }(\%, \text { B) }\end{array}$ & $\begin{array}{c}\text { 着色度当たり } \\
\text { の阻害率 }(\mathrm{B} / \mathrm{A}) \\
\end{array}$ & $\begin{array}{c}\text { 着色物質精製後 } \\
\text { の } \mathrm{B} / \mathrm{A}\end{array}$ \\
\hline 0.5 & 68 & 2.98 & 4.94 & 1.4 & 0.187 & 40.2 & 214.97 & $306.7 \sim 311.5$ \\
\hline 2.5 & 66.1 & 2.92 & 9.91 & 5.9 & 0.698 & 46.6 & 66.76 & $88.82 \sim 111.29$ \\
\hline 4.5 & 82.1 & 3.47 & 13.89 & 7.5 & 1.705 & 53.7 & 31.5 & $31.72 \sim 37.69$ \\
\hline 17 & 129.1 & 4.07 & 17.44 & 18.7 & 12.715 & 79.4 & 6.25 & $4.2 \sim 5.7$ \\
\hline
\end{tabular}

総フェノール量はチロシンとして表示した。FRS：フェリシアナイド還元值， 3 - DG：3-デオキシグルコソン, $\mathrm{ACE}$ : アンジオテンシン I 変換酵素。 


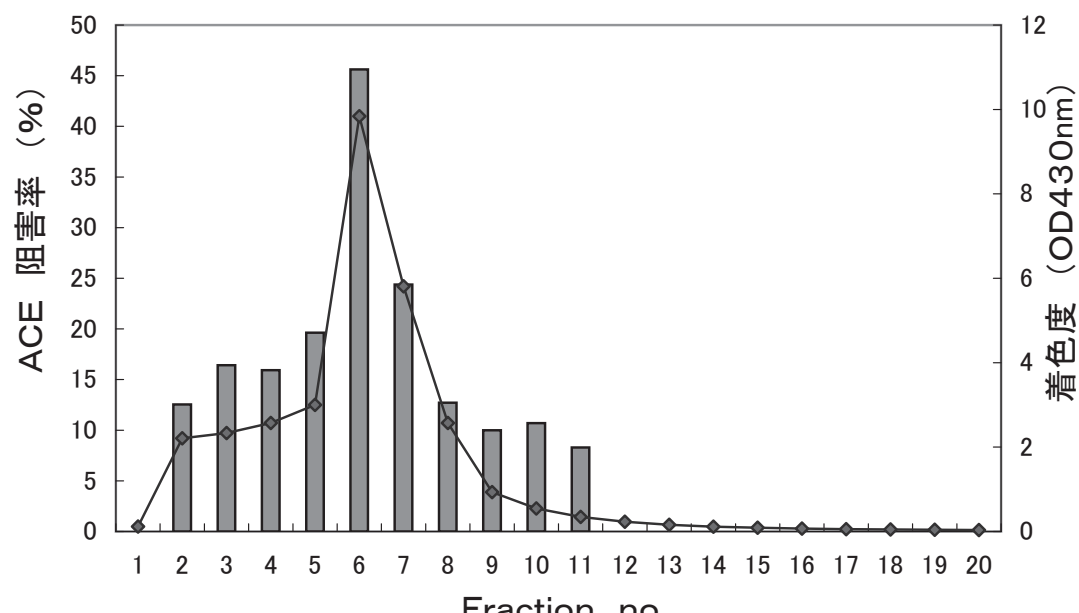

Fraction no.

\section{$\square$ ACE阻害率 $\rightarrow$ O.D.430nm}

第 4 図 17 年貯蔵本みりんの着色物質と ACE 阻害活性との関係

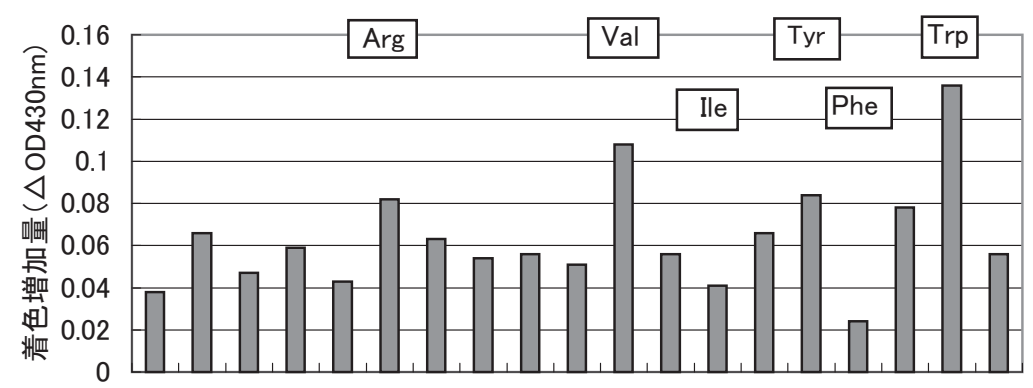

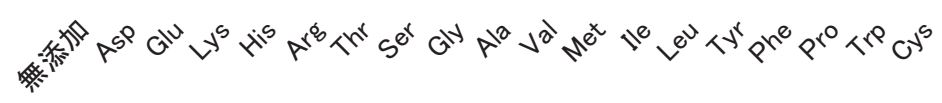

添加したアミノ酸名

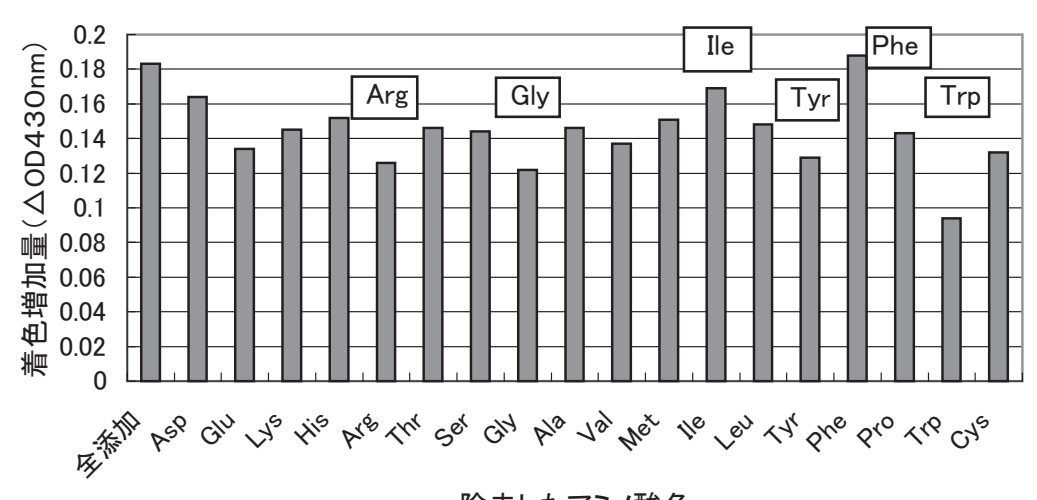

除去したアミノ酸名

$\square$ 着色増加量 $\left(37^{\circ} \mathrm{C}\right.$, 30日 $\left.\triangle \mathrm{OD} 430 \mathrm{~nm}\right)$

第 5 図本みりんの貯蔵着色増への各アミノ酸の影響 
17 年貯蔵本みりん $100 \mathrm{ml}$ を蒸留水で 3 倍に希釈後 前述した方法で DiaionHP20 カラムクロマトグラフィ 一を行い, 各区分の ACE 阻害活性と着色度を測定し た結果を第 4 図に示した。他の試料についても同様の 操作を行い, 各画分について, 精製した着色物質の着 色度当たりの ACE 阻害活性を求め, 第 5 表に示した。

この結果, 着色度と $\mathrm{ACE}$ 阻害率は概ね一致し, 着 色物質メラノイジンが ACE 阻害活性を示すと推定さ れた。また，抗酸化性と同様貯蔵期間が長くなると着 色度当たりの ACE 阻害活性も小さくなった。ACE 阻害活性を示す成分には着色物質のほかにペプチドな ども報告されており ${ }^{8)}$, これらの貯蔵による変化を検 討する必要がある。

\section{5. 本みりんの着色に関与する成分 ${ }^{30)}$}

本みりんの 2 つ機能性には着色物質が関与するこ とが明らかになったが, 本みりんの着色に関する報告 は少なく, 関与成分もまだ不明である。そこで, 着色 増加に関与する成分について検討した。

\section{1）分画画分の着色増加への寄与率}

試験醸造した本みりんをイオン交換樹脂で 4 区分（塩 基性窒素 (C), 中酸性窒素 (R), 酸 (A) 及び中性 (N) 区分) に分画後 ${ }^{8)}, 2^{4}$ の組合わせを行い, $37^{\circ} \mathrm{C}$, 15 日間貯蔵し着色増加量を求めた。分散分析により 着色増加に対する寄与率を求めたところ, R: $46.0 \%$ **, C:28.5\%**, RxC:11.1\%**, N:8.3\%*, CxAxN:2.0\%, $\operatorname{RxN}: 1.9 \%, \operatorname{RxCxAxN}: 1.9 \%(* *(\mathrm{p}<0.01), *(\mathrm{p}$ <0.05）となり，R区分とC区分で $85.5 \%$ を占める ことが分かった。

\section{2）有効画分のアミノ酸による代替}

$\mathrm{R}$ 及び $\mathrm{C}$ 区分を $\mathrm{L}-$ アミノ酸で置換え, 脱アミノ 酸清酒（A+N区分）に18 種類のアミノ酸を $2 \mathrm{mM}$ 濃度になるよう 1 個ずつ添加した試験区及び 18 種類 のアミノ酸を全部添加したものから 1 種類ずつアミノ 酸を除去した試験区を作り，37으. 30 日間貯蔵し, 着色増加量を求め, その結果を第 5 図に示した。この 結果, 無添加区 $(\mathrm{A}+\mathrm{N}$ 区分) に比較して, Phe 以 外全て着色増加がみられたが, 特にTrp, Val, Tyr, Arg を添加した場合増加量が多かった。一方, 全添 加区から 1 個ずつアミノ酸を除いた場合, Phe 以外全 て着色の減少がみられたが，中でも Trp, Gly, Arg, Tyr を除去した場合増加量が抑えられた。以上から，
本みりんの着色増加にはPhe を除きほとんどのアミ ノ酸が関与していることが分かった。しかし，全アミ ノ酸添加区の着色増加量は分画前本みりんの着色増加 量の $68.3 \%$ であった。なお, 貯蔵着色増加に対し, アミノ酸の中で $\operatorname{Trp}$ の関与が最も大きく，そのほか Arg, Tyr, Lys, Glyなどが関与すること，また， Phe 及びIle が着色増加を抑制することはすでに清酒 で報告されている ${ }^{31)}$ 。

\section{6. おわりに}

以上, 本みりんの着色物質が抗酸化性及び ACE 阻 害活性を示し, その着色増加には Trp, Tyr, Arg を はじめとしてほとんどのアミノ酸が関与していること が明らかとなった。着色物質の諸性質及び抗酸化性や ACE 阻害活性がどのようにして引き起こされるかに ついては現在検討中である。

\section{文 献}

1）北本勝ひこ編著：醸造物の機能性, 日本醸造協 会（東京, 2007)

2）河辺達也：醸協, 102(6), 422-431（2007）

3）石崎俊行, 高倉 裕, 吉浜義雄, 平松順一, 高 橋康次郎, 猪飼勝重: 醸協, 98(12), $861-$ 868 (2003)

4）石崎俊行, 吉浜義雄, 平松順一, 高橋康次郎 : 釀協, 101 (11), 839-849（2006）

5）石田丈博, 福井 裕, 松田秀喜, 的場輝佳 : 調 理科学, 38, 480-485 (2005)

6) 松田秀喜, 石田丈博: 調理科学, 37, $76-79$ (2004)

7) 松田秀喜, 福井 裕, 石田丈博, 松井利郎: 調 理科学：38, 426-429 (2005)

8) 福井 裕, 石田丈博, 松田秀喜, 松井利郎: 調 理科学 : 38, 430-434 (2005)

9）竹村朋実, 渡辺清香, 田中万祐子, 進藤斉, 小 泉武夫, 高橋康次郎: 醸協, 106 (8), 547-555

10）黑木龍也, 高橋康次郎: 平成 22 年度東京農業 大学卒業論文 (2010)

11）山口直彦: 澱粉科学, 38, 99 (1991)

12) F.Hayase, S.Hirashima, G.Okamoto and H.Kato : Agric. Biol. Chem., 53, 3383-3385 (1989)

13）早瀬文孝：食品工業，35(2)，18（1992）

14) I.E.Lee, N.V.Chuyen, F.Hayase and H.Kato: Biosci.Biotech.Biochem., 58(1) 18-23 (1994) 
15）飯島剛, 篠田達也, 早瀬文孝, 荒井綜一: 農化, 67, 510 (1993)

16) T.Gomyo and M.Miura: Dev. Food Sci.,13, 549558 (1998)

17) A.Okamoto, H.Hanagata, E.Matsumoto, Y.Kawamura, Y.Koizumi and F.Yanagida: Biosci.Biotech.Biochem., 59(6), 1147-1149 (1995)

18）岡本（具沼）章子, 松本英子, 河村幸雄, 小泉 幸道，柳田藤治：醸協，96(3)，199-206 (2001)

19) H.Kitagaki, M.Tsugawa: J.Biosci. Bioeng., 87, 323-332 (1999)

20）佐藤 信, 中村欣一, 蓼沼 誠, 蓮尾徹夫, 矢 尾武広, 茂木宏治, 重藤久紘: 醸協, 64 (6) $541-546$ (1969)

21）佐藤 信, 中村欽一, 䓇沼 誠, 岩永哲郎：醸 協，63(7)，790-792（1968）

22）岩野君夫, 来間健次, 衣山陽三, 中村伝市, 河 地元彦：䁔協，65(1)，59-62（1970）
23) J.E.Hodge: J.Agric.FoodChem., 1, 928-943 (1953)

24）並木満夫:農化, 59, 811 (1985)

25）佐藤 信, 高橋康次郎, 蓼沼 誠：醸協, 62 (6) , 657-659 (1967)

26) Hofmann,T.: European Food Research and Technology, 206 (4), 251-258 (1998)

27) Qingping $\mathrm{Xu}$, Wenyi Tao, Zonghua Ao: Food Chemistry, 102, $841-849$ (2007)

28）田中万裕子, 進藤 斉, 佐藤和夫, 高橋康次 郎：2011 年度日本農芸化学大会講演要旨集, 235 頁 (2011)

29) Margarita J. Kuntcheva - Tzvetan D. Obretenov: Z lebensm Unters Forsch, 202, 238 - 243 (1996)

30）竹内 涼, 高橋康次郎: 平成 22 年度東京農業 大学卒業論文 (2010)

31）佐藤 信, 中村欽一, 蔡沼 誠, 高橋康次郎, 安岡正博：醸協, 66(7), 723-728（1971） 